\title{
Comparative assessment of microbial enzyme activity with compost and sewage sludge amendment
}

\author{
Jatinder Kaur*, Sandeep Sharma and Hargopal Singh \\ Department of Soil Science, Punjab Agricultural University, Ludhiana-141004 (Punjab), INDIA \\ *Corresponding author. E-mail: jatinder_sandhu@rediffmail.com \\ Received: April 17, 2015; Revised received: October 1, 2015; Accepted: December 12, 2015
}

\begin{abstract}
Changes in soil microbial activities were investigated to examine the effect of aerobically digested sewage sludge (SS) and compared with compost under incubation conditions over 63 days. Sandy soil was amended with $0.25,0.5,1.0$ and $1.5 \% \mathrm{w} / \mathrm{w}$ of compost and sewage sludge. Enzyme activity (dehydrogenase, alkaline phosphatase, acid phosphatase, phytase and urease) were examined at an interval of 3, 7, 14, 21, 28, 42 and 63 days. At the end of the experiment the change in organic carbon, nitrogen, potassium and phosphorus was also recorded. Results indicated that enzyme activities were substantially enhanced in presence of both amendments for first few days and the higher increases were measured at $1.5 \%$ of compost and sewage sludge amendment. Then an overall decrease in enzyme activity was recorded. Both the amendments also significantly increased the organic carbon, nitrogen and potassium of the soil while increase in available phosphorus was only recorded in treatment receiving compost. The present experiment indicated that addition of compost and sewage sludge have positive effect on soil microbial activity and can be safely used as soil amendment without having any adverse effect. Though, a previous examination of sewage sludge to be used must be made for heavy metals and pathogens.
\end{abstract}

Keywords: Compost, Microbial enzyme, Sandy soil, Sewage sludge

\section{INTRODUCTION}

There is an increasing interest in the use of organic amendments in soil management and crop production fostered by the advantage of organics to improve or maintain soil biological, chemical and physical properties (Ferreras et al., 2006; Guerrero et al., 2000; Bouajila and Sanaa, 2011). Compost and sewage sludge are common soil amendments used to improve soil tilth, increasing water holding capacity, porosity, surface area (Cogger, 2005), soil structure (Thomas et al., 1996) and decrease soil bulk density (Curtis and Claassen, 2009), thereby providing an environment that will allow for the growth of healthy root systems. Organic amendments also supply nutrients to growing plants and increase the concentrations of plant-available nutrients in soils.

Compost is considered to be an environmentally safe, agronomically advantageous, and relatively cheap organic amendment which stimulates soil microbial activity and crop growth (Garcia et al., 1994; Pascual et al., 1997; Van-Camp et al., 2004). Decomposition and humification of biodegradable organic waste materials is predominantly carried out by a variety of mesophilic/thermotolerant and thermophilic microorganisms, predominately of soil origin (de Bertoldi et al., 1983). The application of urban industrial sludge mixed with sewage sludge to agricultural soil is generally most economic outlet for waste disposal; in this way it is possible to re-cycle the plant nutrients such as $\mathrm{N}, \mathrm{P}$ and organic matter and many more macro and micro nutrients (Bose and Bhattacharyya, 2012). As a soil conditioner, sludge reduces bulk density and increases porosity, improves structural stability, and enriches soil with organic carbon (Pagliai et al., 1981; Metzger and Yaron, 1987; Tester, 1990; Sort and Alcaniz, 1999; Marinari et al., 2000). Addition of sewage sludge increases basal respiration, microbial biomass, metabolic quotient and ezyme activity in soil (Fernandes et al., 2005). However, due to the physicalchemical processes involved in the treatment, the sludge tends to concentrate heavy metals and poorly biodegradable trace organic compounds as well as potentially pathogenic organisms (viruses, bacteria etc) present in waste waters.

It is essential to determine the effect of compost and sewage sludge on microorganisms and their activity as the microorganisms play key role in nutrient cycling as well as in sustaining soil health. Changes in microbial population and activity precede detectable changes in soil physico-chemical properties as microorganisms have intimate relations with their surroundings due to their high surface to volume ratio (Pankhurst et al., 1995). Soil enzymes derived primarily from soil microbes are considered as indicative measures of soil fertility (Zahir et al., 2001) as they participate in elemental cycling and decomposition of organic residues and are considered fundamentally best indicators for 
soil quality (Caldwell, 2005;Venkatesan and Senthurpandian, 2006; Kizilkaya et al., 2007; Abdalla and Langer, 2009). Therefore, their activity is considered an indicator of the oxidative metabolism in soil and thus also of microbial activity (Quilchano and Maranon, 2002). Dehydrogenase being exclusively intracellular, is linked to viable cells. Dehydrogenase is considered an indicator of the oxidative metabolism in soils and thus of the microbiological activity (Skujins, 1973), because. Urease is one of the enzymes involved in environmental nitrogen transformations and can be used to indicate part of the $\mathrm{N}$ cycling in soil (Park and Hausinger, 1995). It catalyzes the hydrolysis of urea and amides to carbon dioxide and ammonia. It acts on carbon-nitrogen ( $\mathrm{C}-\mathrm{N}$ ) bounds other than peptide linkage (Bremner and Mulvaney, 1978; Karaca et al., 1999). Phosphatase is group of enzymes which cleave the phosphate groups from substrates such as nucleic acid and represents the P-cycle in the sludge-amended soil (Wang et al., 1990). Numerous studies have been conducted to observe effect of compost and sewage sludge on soil physical and chemical properties but very few studies have been undertaken to determine the effect on sewage sludge soil's biological property. The objective of this incubation study was to determine the effect of soil amendments, compost and sewage sludge, on microbial activity and physico-chemical properties of sandy soil.

\section{MATERIALS AND METHODS}

Soil, compost and sludge description: Dewatered anaerobically digested sewage sludge was collected from the sewage treatment plant at Bhattian and stored at $4^{\circ} \mathrm{C}$ until use. Sewage sludge was stabilized at $52^{\circ} \mathrm{C}$ for $24 \mathrm{hr}$ to kill off any pathogens and dried at room temperature for one week. The compost was prepared at Research farm of Punjab Agricultural University, Ludhiana (30 $56^{\circ}$ North, $75^{\circ} 52^{\prime}$ East), Punjab, India, using paddy straw and cow dung. Sewage sludge and compost characteristics are summarized in table 1 . The elemental analysis of compost and sewage sludge is presented in table 2. The plasma atomic emission spectrometer (ICAP-AES) was used to carry out the elemental analysis. Some of these metals, at low concentrations, are essential micronutrients and their limit in sludge, for use in agriculture is $\mathrm{Cd}(20), \mathrm{Cu}$ (1200), Ni (200), Pb (1200), Zn (3000), Hg (25) and Cr (1200) ppm (Goyal et al., 2008). Thus the sewage sludge used in present experiment contained heavy metals within safer limits for agricultural application. The sandy soil was airdried at room temperature and sieved to pass through a $2 \mathrm{~mm}$ sieve. The initial soil characteristics of experimental soil were: $\mathrm{pH} 7.53$, EC $0.197 \mathrm{dS}^{-1}$, organic carbon $0.29 \%$, $\mathrm{KMnO}_{4}$-oxidizable N $37.6 \mathrm{~kg} \mathrm{ha}^{-1}$, Olsen P $27.3 \mathrm{~kg} \mathrm{ha}^{-1}$ and $160.0 \mathrm{~kg} \mathrm{ha}^{-1}$ of ammonium acetate exchangeable $\mathrm{K}$.

Soil treatment and incubation: Stabilized sewage sludge and compost were thoroughly mixed with soil at the rate equivalent to $0.25,0.5,1.0$ and $1.5 \%(\mathrm{w} / \mathrm{w}$ dry weight basis) and filled in polypropylene pots. The amended soil was then moistened to its field capacity and incubated for 63 days at $30^{\circ} \mathrm{C}$. The amended soils were moistened to its field capacity that was kept constant throughout incubation time and were turned daily to provide sufficient oxygen for the system. Sub samples were removed at time intervals of $3,7,14,21,28$, 42 and 63 days to determine the changes in enzyme activities.

Experimental details: Soil without amendment was used as control. The experiment was performed with the following nine treatments (Table 3). The data was subjected to standard analysis of variance (ANOVA) of complete randomized design (Gomez and Gomez, 1984) and the means of the treatments were tested using least significant difference at $5 \%$ probability level by using IRRISTAT data analysis package (IRRI, 2000).

Measurement of soil enzymatic activities: Dehydrogenase (EC 1.1) activity was determined by measuring the amount of an artificial electron acceptor reduced by microbial activity (Camina et al., 1998). To $1 \mathrm{~g}$ fresh soil sample, $0.2 \mathrm{ml}$ of $3 \%$ triphenylterazolium chloride (TTC) and $0.5 \mathrm{ml}$ of $1 \%$ glucose solution was added and incubated for 24 hours at $30^{\circ} \mathrm{C}$. After that $10 \mathrm{ml}$ of methanol was added and kept in refrigerator for $3 \mathrm{hrs}$. The contents were then filtered through Whatman No. 42 filter paper. The samples were washed thoroughly with methanol and the final volume made to $25 \mathrm{ml}$ using methanol. The red colour developed was read at $485 \mathrm{~nm}$. The concentration of dehydrogenase in the sample was obtained from the standard graph using triphenyl foramazan (TPF) (Casida et al., 1964).

The activities of acid (AcdP; EC 3.1.3.2) and alkaline (AlkP; EC 3.1.3.1) phosphatases were assayed on the basis of p-nitrophenol (pNP) release after cleavage of enzyme-specific synthetic substrates at natural soil average $\mathrm{pH}$. $1 \mathrm{~g}$ of fresh soil sample was placed in $50 \mathrm{ml}$ Erlenmeyer flask, and to it $0.2 \mathrm{ml}$ toluene, $4 \mathrm{ml}$ of modified universal buffer $(\mathrm{pH} 6.5$ for assay of acid phosphatase or $\mathrm{pH} 11$ for assay of alkaline phosphatises), $1 \mathrm{ml}$ of p-nitrophenyl phosphate solution made in the same buffer were added. The flasks were stoppered and placed in incubator at $37^{\circ} \mathrm{C}$ for 1 hour. After 1 hour the stopper was removed and $1 \mathrm{ml}$ of $0.5 \mathrm{M}$ $\mathrm{CaCl}_{2}$ and $4 \mathrm{ml}$ of $0.5 \mathrm{M} \mathrm{NaOH}$ was added to the flasks. The soil suspension was then filtered and the yellow colour obtained was spectrophotometrically analyzed at $420 \mathrm{~nm}$. The p-nitrophenol content of the filtrate was calculated by reference to a calibration graph (Tabatabai and Bremner, 1969).

Phytase (EC 3. 1. 3. 8) activity in soil was measured by Ames (1966) method. One $g$ of fresh soil was taken in $15 \mathrm{ml}$ screw capped tubes. To this $4 \mathrm{ml}$ sodium-acetate buffer solution ( $\mathrm{pH} 4.5$ ) and $1 \mathrm{ml}$ of $1 \mu \mathrm{M}$ sodium phytate solution was added. The contents were mixed thoroughly and incubated at $37^{\circ} \mathrm{C}$ for 1 hour. After an hour, the caps were removed and $0.5 \mathrm{ml}$ of $10 \%$ tri- 
Table 1. Physico-chemical properties of sewage sludge and compost.

\begin{tabular}{lcc}
\hline \multicolumn{3}{l}{ Parameters } \\
\hline $\mathrm{pH}$ \\
Electrical conductivity $\left(\mathrm{dS} \mathrm{m}{ }^{-1}\right)$ \\
Available Nitrogen $(\%)$ \\
Olsen Phosphorus $(\%)$ \\
Ammonium acetate exchangeable potassium $(\%)$ \\
\hline \multicolumn{3}{c}{ Table 2. Available metal contents of the sewage sludge and } \\
compost. & \multicolumn{3}{c}{ Concentration $\left(\boldsymbol{\mu g} \mathbf{g}^{-1}\right)$} \\
\multicolumn{3}{c}{ Compost } \\
Metal & Sewage sludge & 1.6 \\
Arsenic & 4 & 7.5 \\
Boron & 17 & 2611 \\
Calcium & 8029 & 0.2 \\
Cadmium & 3.3 \\
Chromium & 10.6 & 2.2 \\
Copper & 62.2 & 6.6 \\
Iron & 7926 & 1085 \\
Potassium & 15372 & 15412 \\
Magnesium & 3592 & 1200 \\
Manganese & 64.7 & 57.7 \\
Sodium & 991 & 2560.6 \\
Nickel & 41 & 8.4 \\
Phosphorus & 4106.4 & 7180 \\
Lead & 87 & 3.8 \\
Sulphur & 2620 & 2260 \\
Zinc & 707 & 103 \\
\hline
\end{tabular}

Table 3. Different treatments used during the study are enlisted below.

\begin{tabular}{|c|c|c|}
\hline S. $\mathbf{N}$. & Acronym & Treatment \\
\hline 1 & Control & Sandy soil without amendment \\
\hline 2 & COM0.25 & $\begin{array}{l}\text { Sandy soil with compost amendment } \\
@ 0.25 \%\end{array}$ \\
\hline 3 & COM0.50 & $\begin{array}{l}\text { Sandy soil with compost amendment } \\
\text { @ } 0.5 \%\end{array}$ \\
\hline 4 & COM1.0 & $\begin{array}{l}\text { Sandy soil with compost amendment } \\
\text { @ } 1.0 \%\end{array}$ \\
\hline 5 & COM1.5 & $\begin{array}{l}\text { Sandy soil with compost amendment } \\
\text { @ } 1.5 \%\end{array}$ \\
\hline 6 & SS0.25 & $\begin{array}{l}\text { Sandy soil with sewage sludge } \\
\text { amendment @ } 0.25 \%\end{array}$ \\
\hline 7 & SS0.5 & $\begin{array}{l}\text { Sandy soil with sewage sludge } \\
\text { amendment @ } 0.50 \%\end{array}$ \\
\hline 8 & SS1.0 & $\begin{array}{l}\text { Sandy soil with sewage sludge } \\
\text { amendment @ } 1.0 \%\end{array}$ \\
\hline 9 & SS1.5 & $\begin{array}{l}\text { Sandy soil with sewage sludge } \\
\text { amendment @ } 1.5 \%\end{array}$ \\
\hline
\end{tabular}

chloroacetic acid was added to stop the reaction. The contents were then filtered through Whatman filter paper no. $1.2 \mathrm{ml}$ of the filtrate was taken in $25 \mathrm{ml}$ volumetric flasks and the test for phosphorus hydrolysed was done using the Olsen method. The inorganic phosphorous was calculated by reference to a calibration graph prepared from standard solution. Phytase activity was expressed as $\mu \mathrm{g}$ inorganic $\mathrm{P}$ released/g soil/hr. Urease (EC 3.5.1.5) activity was assayed by method of Douglas and Bremner (1970). Five g of soil was thoroughly mixed with $5 \mathrm{ml}$ urea solution $\left(2000 \mu \mathrm{g} \mathrm{ml}^{-1}\right)$, and then incubated at $37 \pm 1^{\circ} \mathrm{C}$ for $5 \mathrm{hrs}$. After incubation, the residual urea was extracted with $50 \mathrm{~mL}$ of $2 \mathrm{M}$

\begin{tabular}{cc} 
Sewage sludge & Compost \\
\hline 6.66 & 8.99 \\
4.82 & 8.52 \\
0.64 & 0.88 \\
0.68 & 1.18 \\
0.30 & 2.70 \\
\hline
\end{tabular}

KCl-phenyl mercury acetate solution for $1 \mathrm{~h}$ on a rotary shaker, followed by filtration (Tabatabai, 1994). To $1 \mathrm{ml}$ of filtrate $5 \mathrm{ml}$ of extracting reagent $\left(\mathrm{H}_{3} \mathrm{PO}_{4}\right.$ and $\left.\mathrm{H}_{2} \mathrm{SO}_{4}\right)$ and $15 \mathrm{ml}$ of coloring reagent (diacetylmonoxime and thiosemicarbazide) were added and boiled in water bath for 30 mins. The intensity of red colour obtained after cooling the samples was measured at $527 \mathrm{~nm}$. Soil urease activity was expressed as $\mu \mathrm{g}$ of hydrolyzed urea-N/g soil/h.

Soil physico-chemical analysis: The soil samples after completion of incubation period were analyzed for physico-chemical changes. The samples were airdried and passed through $2 \mathrm{~mm}$ sieve and was analyzed for basic soil parameters $(\mathrm{pH}$, electrical conductivity, organic carbon, mineral nitrogen, Olsen $\mathrm{P}$ and ammonium acetate extractable potassium). Soil $\mathrm{pH}$ in 1:2 soil: water suspension, after 30-min equilibrium time (McLean, 1982), was measured using pH meter, electrical conductivity (EC) was determined in 1:2 soil: water supernatant solutions with the help of Conductivity Bridge. Organic carbon (OC) was determined by Walkley and Black's (1934) rapid titration method using diphenylamine indicator. Available $\mathrm{P}$ was extracted by Olsen's $\mathrm{NaHCO}_{3}$ method (Olsen et al., 1954). Phosphorus in all extracts was determined calorimetrically by the molybdenum blue colour method of Murphy and Riley (1962). Total Kjeldahl nitrogen (TKN) was deter-mined by Kjeldahl digestion followed by ammonia distillation. Ammonium acetate exchangeable $\mathrm{K}$ was determined using flame photometer.

\section{RESULTS AND DISCUSSION}

Considerable variations in dehydrogenase, urease and phosphatase activities were found for the different doses of compost and sewage sludge application under incubation conditions. A rapid and significant increase in enzymatic activities was observed after the addition of compost and sewage sludge followed by a progressive decrease.

Soil dehydrogenase that represents in situ metabolic oxidative activity of soil organisms was significantly influenced by both the organic amendments. The dehydrogenase activity of amended soil increased with increasing rate of application of compost and sewage sludge. The maximum dehydrogenase activity was obtained in treatment COM1.5 (59.44 $\mu$ g TPF $\left.\mathrm{g}^{-1} \mathrm{~h}^{-1}\right)$ followed by SS1.5 $\left(52.72 \mu \mathrm{g}\right.$ TPF g $\left.\mathrm{g}^{-1} \mathrm{~h}^{-1}\right)$ during $14^{\text {th }}$ day of incubation (Table 5). In all the treatments the dehydrogenase increased upto $14^{\text {th }}$ day of incubation and then a decline was obtained with increasing period 
Table 4. Changes in physico-chemical properties of amended soil samples after 63 days of incubation.

\begin{tabular}{|c|c|c|c|c|c|c|}
\hline Treatments & pH & $E C\left(d S m^{-1}\right)$ & OC (\%) & Potassium (kg /ha) & $\begin{array}{c}\text { Available Nitrogen } \\
\text { (kg/ha) }\end{array}$ & Phosphorus (kg/ha) \\
\hline$\overline{\mathrm{C}}$ & 7.71 & 0.195 & 0.28 & 149.33 & 39.72 & 28.80 \\
\hline COM0.25 & 7.64 & 0.199 & 0.35 & 255.73 & 46.00 & 36.90 \\
\hline COM0.50 & 7.69 & 0.201 & 0.39 & 334.13 & 43.90 & 44.13 \\
\hline COM1.0 & 7.69 & 0.202 & 0.42 & 621.60 & 66.90 & 57.27 \\
\hline COM1.5 & 7.66 & 0.213 & 0.46 & 767.20 & 62.72 & 77.63 \\
\hline SS0.25 & 7.68 & 0.199 & 0.32 & 207.20 & 63.39 & 25.43 \\
\hline SS0.5 & 7.56 & 0.0205 & 0.33 & 250.13 & 48.09 & 22.63 \\
\hline SS1.0 & 7.51 & 0.209 & 0.41 & 276.27 & 43.90 & 25.00 \\
\hline SS 1.5 & 7.33 & 0.202 & 0.44 & 268.80 & 50.17 & 27.00 \\
\hline $\operatorname{LSD}(p=0.05)$ & 0.105 & NS & 0.038 & 53.53 & 3.15 & 4.06 \\
\hline
\end{tabular}

Table 5. Dehydrogenase activity $\left(\mu \mathrm{g} \mathrm{TPF} \mathrm{g}^{-1} \mathrm{~h}^{-1}\right)$ of amended soil samples as influenced by incubation period.

\begin{tabular}{lcccccccc}
\hline Treatment & $\mathbf{0 ~ d a y}$ & $\mathbf{3}^{\text {rd }} \mathbf{D a y}$ & $\mathbf{7}^{\text {th }} \mathbf{d a y}$ & $\mathbf{1 4}^{\text {th }} \mathbf{d a y}$ & $\mathbf{2 1}^{\text {st }} \mathbf{d a y}$ & $\mathbf{2 8}^{\text {th }} \mathbf{d a y}$ & $\mathbf{4 2}^{\text {nd }} \mathbf{d a y}$ & $\mathbf{6 3}^{\text {rd }} \mathbf{d a y}$ \\
\hline C & 9.75 & 11.58 & 17.58 & 29.42 & 20.67 & 19.41 & 18.13 & 20.53 \\
COM0.25 & 12.66 & 15.45 & 19.39 & 42.22 & 24.66 & 21.21 & 19.15 & 23.18 \\
COM0.5 & 13.72 & 18.39 & 17.83 & 48.19 & 24.97 & 22.03 & 21.96 & 24.47 \\
COM1.0 & 19.56 & 19.97 & 23.08 & 45.67 & 38.28 & 35.59 & 24.67 & 25.87 \\
COM1.5 & 29.11 & 34.95 & 45.72 & 59.44 & 41.06 & 38.54 & 26.93 & 27.69 \\
SS0.25 & 9.19 & 14.39 & 22.39 & 42.67 & 30.47 & 26.74 & 19.97 & 21.56 \\
SS0.5 & 18.47 & 16.89 & 16.36 & 47.83 & 34.37 & 32.41 & 24.83 & 23.00 \\
SS1.0 & 21.22 & 22.77 & 23.64 & 37.33 & 33.67 & 31.82 & 30.83 & 20.55 \\
SS1.5 & 30.53 & 41.64 & 45.28 & 52.72 & 33.67 & 30.20 & 27.23 & 26.53 \\
LSD (p=0.05) & 2.68 & 2.39 & 2.66 & 5.11 & 1.97 & 1.38 & 3.31 & 1.77 \\
\hline
\end{tabular}

Table 6. Acid phosphatase activity $\left(\mu \mathrm{g} \mathrm{PNP} \mathrm{g}^{-1} \mathrm{~h}^{-1}\right)$ of amended soil samples as influenced by incubation period.

\begin{tabular}{lcccccccc}
\hline Treatments & $\mathbf{0 ~ d a y ~}$ & $\mathbf{3}^{\text {rd }}$ Day & $\mathbf{7}^{\text {th }} \mathbf{d a y}$ & $\mathbf{1 4}^{\text {th }} \mathbf{d a y}$ & $\mathbf{2 1}^{\text {st }}$ day & $\mathbf{2 8}^{\text {th }} \mathbf{d a y}$ & $\mathbf{4 2}^{\text {nd }} \mathbf{d a y}$ & $\mathbf{6 3}^{\text {rd }} \mathbf{d a y}$ \\
\hline C & 1.27 & 2.22 & 3.56 & 4.49 & 2.33 & 2.22 & 1.69 & 1.65 \\
COM0.25 & 3.5 & 4.58 & 4.51 & 6.15 & 4.69 & 4.11 & 3.42 & 3.20 \\
COM0.50 & 4.17 & 6.42 & 5.41 & 7.08 & 6.33 & 4.45 & 3.28 & 3.11 \\
COM1.0 & 5.25 & 6.03 & 6.51 & 9.64 & 12.11 & 11.95 & 12.80 & 12.23 \\
COM1.5 & 5.69 & 8.42 & 11.79 & 12.02 & 16.03 & 14.67 & 15.28 & 13.70 \\
SS0.25 & 5.94 & 6.06 & 7.33 & 5.46 & 8.19 & 8.75 & 7.39 & 7.10 \\
SS0.5 & 3.03 & 16.89 & 8.36 & 9.95 & 7.61 & 9.08 & 9.22 & 8.34 \\
SS1.0 & 5.47 & 13.14 & 6.31 & 9.80 & 6.14 & 6.58 & 6.50 & 6.66 \\
SS1.5 & 10.31 & 13.64 & 9.26 & 9.59 & 4.97 & 6.44 & 5.89 & 5.51 \\
LSD (p=0.05) & 1.20 & 1.23 & 2.03 & 1.21 & 1.76 & 1.27 & 2.36 & 2.18 \\
\hline
\end{tabular}

Table 7. Alkaline phosphatase activity $\left(\mu \mathrm{g} \mathrm{PNP} \mathrm{g}^{-1} \mathrm{~h}^{-1}\right)$ of amended soil samples as influenced by incubation period.

\begin{tabular}{|c|c|c|c|c|c|c|c|c|}
\hline Treatments & 0 day & $3^{\text {rd }}$ Day & $7^{\text {th }}$ day & $14^{\text {th }}$ day & $21^{\text {st }}$ day & $28^{\text {th }}$ day & $42^{\text {nd }}$ day & $63^{\text {rd }}$ day \\
\hline $\mathrm{C}$ & 11.50 & 19.19 & 14.10 & 13.36 & 12.31 & 10.67 & 8.47 & 8.18 \\
\hline COM0.25 & 18.61 & 25.11 & 27.84 & 24.15 & 21.83 & 19.97 & 17.70 & 16.89 \\
\hline COM0.50 & 21.00 & 28.92 & 30.36 & 28.67 & 24.25 & 23.33 & 21.80 & 20.35 \\
\hline COM1.0 & 25.83 & 31.33 & 32.13 & 29.46 & 31.36 & 29.31 & 24.87 & 23.51 \\
\hline COM1.5 & 28.22 & 35.70 & 33.84 & 36.62 & 33.22 & 31.03 & 29.10 & 23.76 \\
\hline SS0.25 & 12.89 & 21.33 & 21.77 & 20.46 & 20.75 & 17.58 & 9.53 & 9.69 \\
\hline SS0.5 & 14.39 & 23.28 & 24.44 & 22.08 & 16.08 & 14.31 & 10.03 & 9.70 \\
\hline SS1.0 & 16.47 & 26.94 & 21.95 & 18.03 & 15.19 & 13.31 & 9.90 & 9.54 \\
\hline SS1.5 & 23.33 & 29.08 & 19.80 & 16.44 & 13.58 & 11.33 & 6.93 & 6.93 \\
\hline $\operatorname{LSD}(\mathrm{p}=0.05)$ & 1.88 & 1.51 & 1.66 & 2.11 & 1.63 & 1.27 & 2.91 & 3.26 \\
\hline
\end{tabular}

of incubation. Soil dehydrogenase activity has been used as a parameter to study biological activity of soil (Wlodarczyk et al., 2002). Since dehydrogenase activity is only present in viable cells, it is thought to reflect the total oxidative activity of soil microflora (Nannipieri et al., 1990; Zhao et al., 2010; Yuan and Yue, 2012) and therefore, is considered as a suitable indicator of soil quality and microbial activity (Salazar et al., 2011; Paz-Ferreiro et al., 2012). Dehydrogenase activity is usually enhanced by labile organic matter addition such as sewage sludge (Serra-Wittling et al.,
1996) and compost. Higher dehydrogenase activity in compost applied plots may be due to higher organic matter content and relatively higher microbial quotient (Cmic) (Wlodarczyk et al., 2002). Sludge is composed of highly oxidizable organic substrates and a large biomass which explains the high intracellular dehydrogenase activity in soil receiving sludge amendment (Garcia et al., 1994). The decline in dehydrogenase activity after $14^{\text {th }}$ day of incubation may be likely due to the depletion of organic substrates, accumulation of metabolic toxins and the decrease in $\mathrm{pH}$ after the peak 
Table 8. Phytase activity ( $\mu \mathrm{g}$ P hydrolyzed $\mathrm{g}^{-1} \mathrm{~h}^{-1}$ ) of amended soil samples as influenced by incubation period.

\begin{tabular}{lcccccccc}
\hline Treatments & $\mathbf{0 ~ d a y}$ & $\mathbf{3}^{\text {rd }} \mathbf{D a y}$ & $\mathbf{7}^{\text {th }} \mathbf{d a y}$ & $\mathbf{1 4}^{\text {th }} \mathbf{d a y}$ & $\mathbf{2 1}^{\text {st }} \mathbf{d a y}$ & $\mathbf{2 8}^{\text {th }} \mathbf{d a y}$ & $\mathbf{4 2}^{\text {nd }} \mathbf{d a y}$ & $\mathbf{6 3}^{\text {rd }}$ day \\
\hline C & 0.279 & 0.569 & 0.565 & 1.033 & 0.887 & 0.931 & 0.62 & 0.369 \\
COM0.25 & 0.349 & 0.517 & 0.660 & 1.288 & 1.029 & 0.972 & 0.66 & 0.459 \\
COM0.50 & 0.534 & 0.733 & 0.707 & 1.284 & 1.110 & 1.138 & 0.73 & 0.555 \\
COM1.0 & 0.802 & 0.753 & 0.935 & 1.984 & 1.744 & 1.558 & 0.88 & 0.681 \\
COM1.5 & 1.304 & 1.221 & 1.246 & 1.897 & 1.920 & 1.885 & 1.03 & 0.806 \\
SS0.25 & 0.397 & 0.423 & 0.375 & 1.086 & 0.718 & 0.758 & 0.42 & 0.788 \\
SS0.5 & 0.239 & 0.320 & 0.263 & 0.756 & 0.872 & 0.688 & 0.43 & 0.309 \\
SS1.0 & 0.391 & 0.323 & 0.298 & 0.565 & 0.640 & 0.485 & 0.29 & 0.297 \\
SS1.5 & 0.299 & 0.272 & 0.287 & 0.569 & 0.625 & 0.576 & 0.30 & 0.346 \\
LSD (p=0.05) & 0.511 & 0.174 & 0.064 & 0.225 & 0.237 & 0.139 & 0.059 & 0.065 \\
\hline
\end{tabular}

Table 9. Urease activity ( $\mu \mathrm{g}$ urea $\mathrm{N}$ hydrolyzed $\mathrm{g}^{-1} \mathrm{~h}^{-1}$ ) of amended soil samples as influenced by incubation period.

\begin{tabular}{lcccccccc}
\hline Treatments & $\mathbf{0 ~ d a y ~}$ & $\mathbf{3}^{\text {rd }}$ Day & $\mathbf{7}^{\text {th }}$ day & $\mathbf{1 4}^{\text {th }} \mathbf{d a y}$ & $\mathbf{2 1}^{\text {st }}$ day & $\mathbf{2 8}^{\text {th }}$ day & $\mathbf{4 2}^{\text {nd }} \mathbf{d a y}$ & $\mathbf{6 3}^{\text {rd }} \mathbf{d a y}$ \\
\hline C & 81.80 & 190.43 & 111.67 & 104.33 & 76.23 & 77.33 & 49.43 & 60.00 \\
COM0.25 & 87.77 & 206.20 & 134.00 & 130.00 & 96.23 & 94.67 & 61.93 & 70.33 \\
COM0.50 & 95.97 & 222.67 & 167.50 & 157.33 & 111.10 & 112.23 & 53.90 & 84.33 \\
COM1.0 & 106.20 & 243.33 & 185.17 & 160.83 & 120.43 & 125.57 & 107.20 & 98.33 \\
COM1.5 & 123.77 & 251.13 & 191.67 & 163.33 & 139.33 & 143.97 & 88.33 & 133.67 \\
SS0.25 & 89.10 & 177.10 & 128.50 & 118.83 & 120.23 & 122.00 & 49.43 & 49.67 \\
SS0.5 & 98.67 & 190.43 & 149.83 & 128.00 & 124.20 & 124.90 & 68.03 & 93.67 \\
SS1.0 & 118.67 & 189.33 & 154.83 & 108.00 & 116.00 & 114.23 & 106.63 & 78.00 \\
SS1.5 & 121.10 & 198.43 & 157.50 & 109.00 & 103.53 & 97.77 & 71.40 & 41.67 \\
LSD (p=0.05) & 6.42 & 8.27 & 8.35 & 14.31 & 9.3 & 11.76 & 25.76 & 16.83 \\
\hline
\end{tabular}

of mineralization (Obbard et al., 1994).

Unamended soil had a lower acid phosphatase activity than soil amended with sewage sludge and compost (Table 6). The acid phosphatase activity of all the treatment groups showed the same trend of change with an initial high and then a decline to a relatively constant level over incubation period. With increasing dose of compost application an increase in phosphatase activity was obtained. In COM0.25 and COM0.5 treatment increase in acid phosphatase activity was recorded till $14^{\text {th }}$ day while in treatment COM1.0 and COM1.5, the increase in activity was observed till $21^{\text {st }}$ day of incubation. This may be attributed to more availability of organic matter for microbial proliferation. In compost treatments maximum activity was obtained in treatment COM1.5 on $21^{\text {st }}$ day of incubation. Crecchio et al. (2004) found a positive correlation between compost addition to soil and phosphatase activity.

In sewage treated soils, an overall high acid phosphatase activity was obtained in SS0.5 as compared to other treatments. Maximum activity was obtained in SS0.5 $\left(16.89 \mu \mathrm{g}\right.$ PNP g $\left.{ }^{-1} \mathrm{~h}^{-1}\right)$ on $3^{\text {rd }}$ day of incubation. An alternate increasing and decreasing trend of acid phosphatase activity was obtained in sewage sludge treated soils. Maximum increase in activity was obtained on $3^{\text {rd }}$ day of incubation.

Significantly detectable increases also occurred for alkaline phosphatase activity in the presence of compost. Increase in rate of compost application resulted in an increase in enzyme activity. Maximum acid phosphatase activity was obtained in COM1.5 (36.62 $\mu \mathrm{g}$ PNP $\mathrm{g}^{-1} \mathrm{~h}^{-1}$ ) on $14^{\text {th }}$ day of incubation. While in case of COM0.25, COM0.5 and COM1.0 maximum activity was obtained on $7^{\text {th }}$ day of incubation. As compared to sludge treated soil, compost treated soil gave higher acid phosphatase activity. An increasing trend of acid phosphatase activity was obtained in SS0.25 $(21.77 \mu \mathrm{g}$ PNP g $\left.\mathrm{g}^{-1}\right)$ and SS0.5 (24.44 $\left.\mu \mathrm{g} \mathrm{PNP} \mathrm{g}^{-1} \mathrm{~h}^{-1}\right)$ until $7^{\text {th }}$ day of incubation followed by decline till steady activity was obtained while in SS1.0 and SS1.5, alkaline phosphatase activity increased only until $3^{\text {rd }}$ day followed by decrease in activity with increase in incubation period. Maximum alkaline phosphatase activity in case of sludge treated soil was obtained in treatment SS1.5 (29.08 $\left.\mu \mathrm{g} \mathrm{PNP} \mathrm{g}^{-1} \mathrm{~h}^{-1}\right)$ on $3^{\text {rd }}$ day of incubation (Table 7).

The increase in phosphatase activities of amended soils was partly due to the direct contribution of phosphatase activities from compost and sewage sludge, and partly due to the stimulation of phosphatase production by microflora (Criquet et al., 2007). According to Kizilkaya and Bayrakli (2005), sewage sludge amendment increases the content of readily available substrates in soils thereby promoting the growth of microorganisms. Among these available substrates, organic matter in sludge usually contains high amounts of substrates of acid and alkaline phosphomonoesterases (Garcia et al., 1993) and of phosphodiesterases (Turner and Haygarth, 2005). The subsequent decrease in phosphatase activity might be due to the fact that sludge adds quite substantial amounts of $\mathrm{C}$ and $\mathrm{N}$ to the soil, thereby increasing microbial activity and thus $\mathrm{P}$ demand and release of phosphatases. Over time, $\mathrm{C}$ is depleted, resulting in lower microbial activity, lower $\mathrm{P}$ demand and thus less phosphatase activity (Allison and Vitousek, 2005). Pascual et al. (2002) attributed this decrease to depletion of biodegradable substrates by microbial activity, including the substrates of different phosphatises. 
Overall alkaline phosphatase activity was two to three folds more as compared to acid phosphatase activity. Alkaline phosphates originate from soil bacteria, fungi and fauna (Nakas et al., 1987; Tarafdar and Claassen, 1988). Microbes can produce and release large amounts of extracellular phosphatase due to their combined biomass, high metabolic activity and short life cycles (Speir and Ross, 1978). The activity of alkaline phosphatase is linked not only to the synthesis of animal and microbial cells (Juma and Tabatabai, 1988), but also to the transformation of organic to inorganic phosphorus (Yang et al., 2008). The acid phosphatase activity on the other hand was found to be lower in both the organic amendments. It might be due to that plant roots are major producers of acid phosphatase (Speir and Cowling, 1991; Dinkelaker and Marschner, 1992). Moreover, soil acid phosphomonoesterase activity was higher at low inorganic $\mathrm{P}$ content of soil than at high content, and the enzyme activity was significantly correlated with herbage yield, probably due to the importance of organic $\mathrm{P}$ mineralization for plant nutrition (Speir and Cowling, 1991). Acid and alkaline phosphatase activities were significantly higher in sewage sludge and compost than unamended soil. The increase in activity of hydrolase enzymes might be due to higher levels of intracellular and/or extracellular enzymes, immobilized by recalcitrant humic moieties (Nannipieri, 1994).

Phytase was the only enzyme negatively affected by sludge treatment. The phytase activity of all the sludge treated soil samples on 0 day was at par with the control while with increase in incubation period and with an in increase in rate of sludge amendment, the phytase activity was significantly reduced (Table 8). The reduced activity of phytase may be attributed to high content of Iron (Fe) in sewage sludge. Soni et al. (2010) reported Fe has negative effect on phytase activity. Acuña et al. (2011) reported inhibition of phytase activity by $30-100 \%$ in presences of $10 \mathrm{mM}$ of $\mathrm{Fe}^{+3}$ in Paenibacillus sp. In case of compost amended soil samples significantly higher phytase activity was obtained in COM1.0 and COM1.5 throughout incubation study. Maximum phytase activity was obtained in COM1.0 (1.984 $\mu \mathrm{g}$ P hydrolyzed $\mathrm{g}^{-1} \mathrm{~h}^{-1}$ ) followed by COM1.5 (1.920 $\mu \mathrm{g}$ P hydrolyzed $\left.\mathrm{g}^{-1} \mathrm{~h}^{-1}\right)$ on $14^{\text {th }}$ and $21^{\text {st }}$ day of incubation respectively.

Unamended soil had lowest urease activity compared to that of soil amended with compost and sewage sludge. The maximum urease activity was obtained on $3^{\text {rd }}$ day of incubation in both sewage sludge and compost treated soil (Table 9). In comparison to sludge treated soil, the compost amendment gave higher urease activity. Maximum urease activity was obtained in COM1.5 (251.13 $\mu \mathrm{g}$ urea $\mathrm{N}$ hydrolyzed $\left.\mathrm{g}^{-1} \mathrm{~h}^{-1}\right)$ on $3^{\text {rd }}$ day of incubation. Lai et al. (1999) showed the same trend of change with an initial high and then a decline to a relatively constant level. The higher urease activity at the beginning of incubation is likely due to the high substrate concentration in the amended soil.
Moreover, wetting of dry soil causes the lysis of microbial cells which released the intracellular urease to degrade urea and its derivatives (Ladd and Jackson, 1982; Tabatabai, 1982; Singh and Nye, 1984). In addition, some protected urease bound to microbial cellular components and organic matters would also be released (Singh and Nye, 1984). The reason for the subsequent decline in urease activity after the peak activity may be due to the depletion of substrates and accumulation of toxic metabolites. In addition, during the incubation, free urease would be attacked by soil protease as well as re-bound into the microbial cellular components which would potentially reduce the activity and amount of urease in the soil (Singh and Nye, 1984).

Compost addition did not significantly affected soil $\mathrm{pH}$ and EC while increasing rate of sludge application significantly decreased soil $\mathrm{pH}$ as compared to control (Table 10). The decrease in $\mathrm{pH}$ was caused by the generation of organic acids from the mineralization of organic substrates. Moreover, the nitrification process taking place at this later period might also be responsible for the decrease in $\mathrm{pH}$ (Lai et al., 1999). Soil amended with sewage sludge $\geq 0.5 \%$ showed significant $\mathrm{pH}$ decrease, suggesting that these treatment groups had a higher decomposition rate. All treatment showed an increase in organic carbon content at the end of incubation period in comparison to control. With increasing dose of both the amendments an increase in OC was obtained. Marschner et al. (2003) reported an increase in organic carbon on addition of organic material to soil. They reported $0.82 \%$ organic carbon in organic matter amended soil as compared to $0.67 \%$ in control. The addition of compost and sludge resulted in significant increase in ammonium acetate extractable potassium. There was significant increase in potassium level with increasing rate of soil amendments. Extractable potassium was significantly more in compost amended soil when compared with sludge treated soil with same dose of organic amendment. Maximum potassium was obtained in treatment COM1.5 (767.20 kg/ha). Similarly, a significant increase in Olsen $\mathrm{P}$ was observed in case of soil amended with compost. Increasing the dose of compost lead to a significant increase in Olsen P. Kabirinejad and Hoodaji (2012) also obtained similar results. An increase in phosphorus from $44.5 \mathrm{mg} \mathrm{kg}^{-1}$ to $73 \mathrm{mg}$ $\mathrm{kg}^{-1}$ was recorded by them and attributed the increase in Olsen $\mathrm{P}$ content due to the increase in microbial enzyme activity.

\section{Conclusion}

The present work revealed no apparent detrimental influence of both organic amendments on the studied soil quality indicators. Infact, positive effect on soil microbial enzymes has been observed. Moreover an increase in nutrient availability has also been recorded. It was concluded that soil enzymatic activities 
(dehydrogenase, phosphatase, phytase and urease) of the soil were the most important parameters for assessing soil quality in the environment resulting from use of sewage sludge and compost as amendments .Therefore, compost and sewage sludge can be used as soil amendments after examining their heavy metal and pathogen load which must be within safe limits.

\section{REFERENCES}

Abdalla, M.A. and Langer, U. (2009). Soil enzymes activities in irrigated and rainfed vertisols of the semi-arid tropics of Sudan. Int. J. Soil Sci., 4: 67-79.

Acuña, J.J., Jorquera, M.A, Martínez, O.A., MenezesBlackburn, D., Fernández, M.T., Marschner, P., Greiner, R. and Mora, M.L. (2011). Indole acetic acid and phytase activity produced by rhizosphere bacilli as affected by $\mathrm{pH}$ and metals. Journal of Soil Science and Plant Nutrition, 11: 1-12

Allison, S.D. and Vitousek, P.M. (2005). Responses of extracellular enzymes to simple and complex nutrient inputs. Soil Biology and Biochemistry, 37: 937-944

Ames, B.N. (1966). Assay of inorganic phosphate, total phosphate and phosphatases. Methods Enzymol., 8: 115118

Bouajila, K. and Sanaa, M. (2011). Effects of organic amendments on soil physico-chemical and biological properties. J. Mater. Environ. Sci., 485-490

Bose, S. and Bhattacharyya, A.K. (2012) Effect of industrial sludge application on soil nitrogen and wheat plant response. Open Journal of Soil Science, 2: 133-145

Bremner, J.M. and Mulvaney, R.L. (1978). Urease Activity in Soil. In: R.G. Burns, Ed., Soil Enzymes, Academic Press, New York, pp. 149-196.

Caldwell, B.A. (2005). Enzyme activities as a component of soil biodiversity: A review. Pedobiologia, 49: 637-644.

Camina, F., Trasar, C.C., Sotres, G.F. and Leiros, C. (1998). Measurement of dehydrogenase activity in acid soil rich in organic matter. Soil Biology \& Biochemistry, 33: 1005-1011.

Casida, L.E., Kklein, D.A. and Santoro, T. (1964). Soil dehydrogenase activity. Soil Science, 98: 371-376

Chiu, C.Y. and Tian, G. (2011). Chemical structure of humic acids in biosolids-amended soils as revealed by NMR spectroscopy. Appl. Soil. Ecol., 49: 76-80.

Cogger, C.G. (2005). Potential compost benefits for restoration of soils disturbed by urban development. Compost Sci. Util., 13: 243-251.

Crecchio, C., Curci, M., Pizzigallo, M.D.R., Ricciuti, P. and Ruggiero P. (2004). Effects of municipal solid waste compost amendments on soil enzyme activities and bacterial genetic diversity. Soil Biol. Biochem., 36: 1595 -1605 .

Criquet, S., Braud, A. and Neble, S. (2007). Short-term effects of sewage sludge application on phosphatase activities and available $\mathrm{P}$ fractions in mediterranean soil. Soil Biol Biochem., 39: 921-929

Curtis, M.J. and Claassen, V.P. (2009). Regenerating topsoil functionality in four drastically disturbed soil types by compost incorporation. Restor. Ecol., 17: 24-32.

de Bertoldi, M., Vallini, G. and Pera, A. (1983). The biology of composting: a review. Waste Management and Research, 1: 157-176

Díaz, E., Roldán, A., Lax, A. and Albaladejo, J. (1994). For- mation of stable aggregates in degraded soil by amendment with urban refuse and peat. Geoderma, 63: 277288.

Dinkelaker, B. and Marschner, H. (1992). In vivo demonstration of acid phosphatase activity in the rhizosphere of soil-grown plants. Plant and Soil, 144: 199-205.

Douglas, L.A. and Bremner, J.M. (1970). Extraction and colorimetric determination of urea in soils. Soil Science Society of America Proceedings, 34:859-862

Fernandes, S.A.P, Bettiol, W. and Cerri, C.C. (2005). Effect of sewage sludge on microbial biomass, basal respiration, metabolic quotient and soil enzymatic activity. Applied Soil Ecology, 30: 65-77

Ferreras, L., Gomez, E., Toresani, S., Firpo, I. and Rotondo, R. (2006). Effect of organic amendments on some physical, chemical and biological properties in a horticultural soil. Bioresour Technol., 97: 635-40.

Garcia, C., Hernandez, T., Costa, C., Ceccanti, B., Masciandaro, G. and Ciardi, C. (1993). A study of biochemical parameters of composted and fresh municipal wastes. Bioresour Technol., 44: 17-23

Garcia, C., Hernandez, T., Costa, F. and Ceccanti, B. (1994). Biochemical parameters in soil regenerated by addition of organic wastes. Waste Management \& Research, 12: 457-466

Gomez, K.A. and Gomez, A.A. (1984). Statistical Procedures for Agricultural Research. 2nd Edition, John Wiley and Sons Inc., New York, USA., ISBN: 139780471879312, Pages: 680.

Goyal, S., Walia, M., Kapoor, K.K. and Kundu, B.S. (2008). Impact of sewage sludge application on soil microbial biomass, microbial processes and plant growth- a review. Agric. Rev., 29: 1-10

Guerrero, C., Gõmez, I., Mataix-Solera, J., Moral, R.., Mataix-Beneyto, J. and Hernandez, M.T. (2000). Effect of solid waste compost on microbiological and physical properties of a burnt forest soil in field experiment. Biology and Fertility of Soils, 32: 410-414

International Rice Research Institute (IRRI). (2000). IRRISTAT for window (CD-ROM)

version 4.02b. Los Baños, Philippines;IRRI.

Juma, N.G. and Tabatabai, M.A. (1988). Phosphatase activity in corn and soybean roots: conditions for assay and effects of metals. Plant Soil, 107:39-47

Kabirinejad, S. and Hoodaji, M. (2012). The effects of biosolid appliaction on soil chemical properties and Zea mays nutrition. International Journal of Recycling of Organic Waste in Agriculture, 1:4

Karaca, A., Haggblomb, M.M. and Tate III, R.L. (1999). Effects of the Land Application of Sewage Sludge on Soil Heavy Metal Concentrations and Soil Microbial Sewage Sludge and Soil Urease Activity 147 Communities. Soil Biology and Biochemistry, 31: 1467-1470.

Kizilkaya, R. and Bayrakli, B. (2005). Effects of N-enriched sewage sludge on soil enzyme activities. Applied Soil Ecology, 30: 192-202.

Kizilkaya, R., Bayrakli, F. and Surucu, A. (2007). Relationship between phosphatase activity and phosphorus fractions in agricultural soils. Int. J. Soil Sci., 2: 107118.

Ladd, J.N. and Jackson, R.B. (1982). Biochemistry of ammonification. In F J Stevenson, F. J. (ed.), Nitrogen in Agricultural Soils, American Society of Agronomy, WI. pp. 173-228. 
Lai, K.M., Ye, D.Y. and Wong, J.W.C. (1999). Enzyme activities in a sandy soil amended with sewage sludge and coal fly ash. Water, Air and Soil Pollution, 113: 261 $-272$

Marinari, S., Masciandaro, G., Ceccanti, B. and Grego, S. (2000). Influence of organic and mineral fertilisers on soil biological and physical properties. Bioresour. Technol. 72:9-17

Marschner, P., Kandeler, E. and Marschner, B. (2003). Structure and function of the soil microbial community in a long-term fertilizer experiment. Soil Biol. Biochem., 35: 453-461

McLean, E.O. (1982). Soil $\mathrm{pH}$ and lime requirement. In Page, A.L., R.H. Miller and D.R. Keeney (eds.) Methods of soil analysis. Part 2 - Chemical and microbiological properties. (2nd Ed.). Agronomy, 9: 199-223.

Metzger, L. and Yaron, B. (1987). Influence of sludge organic matter on soil physical properties. p. 141-163. In B.A Stewart (ed.) Advances in soil science, Vol. 7. Springer, New York.

Murphy, J. and Riley, J.P. (1962). A modified single solution method for determination of phosphate in natural waters. Analytical Chimica Acta., 27: 31-36.

Nakas, J.P., Gould, W.D. and Klein, D.A. (1987). Origin and expression of phosphatase activity in a semi-arid grassland soil. Soil Biology and Biochemistry, 19: 1318.

Nannipieri, P. (1994). The potential use of soil enzymes as indicators of productivity, sustainability and pollution. In: Pankhurst, C.E., Doube, B.M., Gupta, V.V.S.R., Grace, P.R. (Eds.), Soil biota. Management in Sustainable Farming Systems. CSIRO, East Melbourne, pp. 238-244.

Nannipieri, P., Grego, S. and Ceccanti, B. (1990). Ecological significance of the biological activity in soil. In: Soil Biochemistry, Volume 6 (eds J.-M. Bollag \& G. Stotzky), pp. 293-355. Marcel Dekker, New York

Obbard, J.P., Sauerbeck, D. and Jones, K.C. (1994). Dehydrogenase activity of the microbial biomass in soils from a field experiment amended with heavy metal contaminated sewage sludges. Sci Total Environ., 142: $157-162$

Olsen, S.R., Cole, C.V., Watanabe, F.S. and Dean, I.A. (1954). Estimation of available phosphorus in soils by extraction with sodium bicarbonate. U.S. Department of Agriculture Circ., 939: 1-19.

Pagliai, M., Guidi, G., La Marca, M., Gichetti, M. and Lucamante, G. (1981). Effect of sewage sludges and composts on soil porosity and aggregation. J. Environ. Qual.,10:556-561.

Pankhurst, C.E., Hawke, B.G., McDonald, H.J., Kirkby, C.A., Buckerfield, J.C., Michelsen, P., O'Brien, K.A., Gupta, V.V.S.R and Doube, B.M. (1995). Evaluation of soil biological properties as potential bioindicators of soil health. Australian Journal of Experimental Agriculture, 35: 1015-1028 